\title{
Factors confounding fluorescein-guided malignant glioma resections: edema bulk flow, dose, timing, and now: imaging hardware?
}

\author{
Walter Stummer ${ }^{1}$ \\ Received: 20 November 2015 / Accepted: 24 November 2015 / Published online: 7 December 2015 \\ (C) The Author(s) 2015. This article is published with open access at Springerlink.com
}

Dear Sir,

I thank you for the opportunity to comment a letter to Acta Neurochirurgica by Dr. Bongetta and coworkers regarding low-price tailored hardware for fluorescein imaging during the resection of malignant gliomas. This group advocates the use of simple blue light available with commercially available endoscopy systems for excitation and a commercially available yellow optical filter fit to the microscope oculars for observation of fluorescence. The argumentation on their side is that more affordable systems would help those surgeons with low budgets and lack of assets to have access to fluorescence-guided resections.

Similar solutions, on a side note, are also available for ALA porphyrin imaging, using filters with exactly the same specifications incorporated into currently available Zeiss or Leica microscopes (D-Light, Storz, Tuttlingen, Germany). In fact, we ourselves began with handheld filters and a xenon light source filtered for blue-violet light (375-440 nm) using identical filters (unpublished data). Unfortunately, even though these systems are available, their versatility during surgery is restricted. The full potential of fluorescence imaging comes from the integration into the operating microscope, which, as the authors correctly point out, is also the most expensive solution. So given a confirmed usefulness of a particular fluorophore for fluorescence-guided resections, cheaper

This manuscript describes the unapproved (off-label) use of an investigational drug, fluorescein.

Walter Stummer

walter.stummer@ukmuenster.de

1 Neurochirurgische Klinik, Universitätsklinikum Münster, Albert-Schweitzer-Campus 1, Gebäude A1, 48149 Münster, Germany solutions might be available and the authors are correct in pointing this out.

However, the authors' proposal also raises new concerns regarding fluorescein-guided resections, and that is the possible influence of the hardware on what the surgeon sees. Investigators of fluorescein are currently using multitudes of different doses and timing, between 3 and $20 \mathrm{mg} / \mathrm{kg}$, administered by either acute injections, injections before opening of the dura, or injections after induction of anesthesia [1-3, 5-9].

Personally, I would prefer (if at all) 3-4 mg fluorescein administered after induction of anesthesia, according to our experience with the method $[10,11]$ using the Zeiss Yellow 560 filter module. This particular mode of use was defined by Ascerbi et al. [1, 2] using the same Zeiss filter system, which has (proprietary) transmission characteristics, and was an important impetus for currently reconsidering the use of fluorescein in malignant glioma and vascular surgery, the former use first described in 1948 [6]. To this end, it remains to be established whether the low-cost solution by Bongetta et al. shows the same type of tissue delineation that appears to be observed using the Yellow 560 filter and whether earlier observations can simply be extrapolated to their particular fluorescein imaging solution.

A different hardware solution with differing light source and detection filter specifications provides new confounders to a technique, which is already beset with multiple variables.

Unfortunately, the basic problems involving fluorescein (a marker of blood-brain barrier integrity) [12] for fluorescence-guided resections remain under investigated. If given too acutely, fluorescein concentrations will be high in all perfused tissues and vessels. In this situation, if tissue is perturbed by surgery, there is unspecific extravasation of fluorescein unrelated to tumor, especially along the resection margins. If, conversely, fluorescein is given with too 
long of a delay to the actual resection, there are legitimate concerns about where the fluorescein is going in the brain, whereas the problems with unspecific extravasation at the resection margins remains remain. Tumor-related edema in the brain, which was intensely investigated in the 1970s and $1980 \mathrm{~s}$, will transverse tissue at a speed exceeding $2 \mathrm{~mm}$ per hour [4] in patients. With 2 to $3 \mathrm{~h}$ between administration of fluorescein and interrogation of tissue, this marker will unspecifically have traversed white matter up to $5 \mathrm{~mm}$, a worrisome thought in the context of an intraoperative tumor marker.

These confounders have to be kept in mind for fluorophores that do not have a specific tumor-fluorophore interaction, as is the case for fluorescein [3]. Thus, while I agree with Bongetta et al. that less-costly hardware solutions would be helpful for dissemination of many techniques in neurosurgery, the biological or theoretical basis for any technique needs to be well defined and the solutions should not provide an additional confounder in an already-complex environment.

Sincerely,

\section{Walter Stummer}

Acknowledgments This letter describes the unapproved (off-label) use of an investigational agent (fluorescein).

\section{Compliance with ethical standards}

Disclosures Walter Stummer has received consultant fees from Medac and speakers fees from Zeiss.

Conflicts of interest None.

Open Access This article is distributed under the terms of the Creative Commons Attribution 4.0 International License (http:// creativecommons.org/licenses/by/4.0/), which permits unrestricted use, distribution, and reproduction in any medium, provided you give appropriate credit to the original author(s) and the source, provide a link to the Creative Commons license, and indicate if changes were made.

\section{References}

1. Acerbi F, Broggi M, Eoli M, Anghileri E, Cavallo C, Boffano C, Cordella R, Cuppini L, Pollo B, Schiariti M, Visintini S, Orsi C, La Corte E, Broggi G, Ferroli P (2014) Is fluorescein-guided technique able to help in resection of high-grade gliomas? Neurosurg Focus 36:E5

2. Acerbi F, Broggi M, Eoli M, Anghileri E, Cuppini L, Pollo B, Schiariti M, Visintini S, Ori C, Franzini A, Broggi G, Ferroli P (2013) Fluorescein-guided surgery for grade IV gliomas with a dedicated filter on the surgical microscope: preliminary results in 12 cases. Acta Neurochir (Wien) 155:1277-1286

3. Diaz RJ, Dios RR, Hattab EM, Burrell K, Rakopoulos P, Sabha N, Hawkins C, Zadeh G, Rutka JT, Cohen-Gadol AA (2015) Study of the biodistribution of fluorescein in glioma-infiltrated mouse brain and histopathological correlation of intraoperative findings in highgrade gliomas resected under fluorescein fluorescence guidance. $\mathrm{J}$ Neurosurg 3:1-10

4. Gröger U, Huber P, Reulen HJ (1994) Formation and resolution of human peritumoral brain edema. Acta Neurochir Suppl (Wien) 60: 373-374

5. Li Y, Rey-Dios R, Roberts DW, Valdés PA, Cohen-Gadol AA (2014) Intraoperative fluorescence-guided resection of high-grade gliomas: a comparison of the present techniques and evolution of future strategies. World Neurosurg 82:175-185

6. Moore GE, Peyton WT, French LA, Walker WW (1948) The clinical use of fluorescein in neurosurgery; the localization of brain tumors. J Neurosurg 5:392-398

7. Okuda T, Yoshioka H, Kato A (2012) Fluorescence-guided surgery for glioblastoma multiforme using high-dose fluorescein sodium with excitation and barrier filters. J Clin Neurosci 19:1719-1722

8. Rey-Dios R, Cohen-Gadol AA (2013) Technical principles and neurosurgical applications of fluorescein fluorescence using a microscope-integrated fluorescence module. Acta Neurochir (Wien) 155:701-706

9. Schebesch KM, Proescholdt M, Höhne J, Hohenberger C, Hansen E, Reimenschneider MJ, Ullrich W, Doenitz C, Schlair J, Lange M, Brawanski A (2013) Sodium fluorescein-guided resection under the YELLOW 560-nm surgical microscope filter in malignant brain tumor surgery — a feasibility study. Acta Neurochir (Wien) 155:693-699

10. Schwake M, Stummer W, Suero Molina EJ, Wölfer J (2015) Simultaneous fluorescein sodium and 5-ALA in fluorescenceguided glioma surgery. Acta Neurochir (Wien) 157(5):877-879

11. Stummer W (2015) Fluorescein in brain metastasis and glioma surgery. Acta Neurochir (Wien) 157:2199-2200

12. Stummer W, Götz C, Hassan A, Heimann A, Kempski O (1993) Kinetics of Photofrin II in perifocal brain edema. Neurosurgery 33: 1075-1081 